\title{
Effect of natural zeolite on live weight changes, ruminal fermentation and nitrogen metabolism of ewe lambs
}

\author{
J.A. Roque-Jiménez ${ }^{1}$, J.M. Pinos-Rodríguez ${ }^{2}$, R. Rojo-Rubio $^{3}$, G.D. Mendoza ${ }^{4}$, A. Vazquez $^{1}$, \\ J.A. Cayetano De Jesus ${ }^{1}$ \& H.A. Lee-Rangel ${ }^{1 \#}$ \\ ${ }^{1}$ Facultad de Agronomía y Veterinaria, Universidad Autónoma de San Luis Potosí, México \\ ${ }^{2}$ Facultad de Medicina Veterinaria y Zootecnia, Universidad Veracruzana, Mexico \\ ${ }^{3}$ Centro Universitario UAEM- Temascaltepec, Universidad Autónoma del Estado de México, México \\ ${ }^{4}$ Departamento de Producción Agrícola y Animal, Universidad Autónoma Metropolitana Xochimilco. México DF
}

(Received 10 October 2017; Accepted 7 September 2018; First published online 21 January 2019)

Copyright resides with the authors in terms of the Creative Commons Attribution 4.0 South African License.
See: http://creativecommons.org/licenses/by/4.0/za
Condition of use: The user may copy, distribute, transmit and adapt the work, but must recognize the authors and the South African
Journal of Animal Science

\begin{abstract}
The objective of this study was to evaluate the effects of natural zeolite on the performance and nitrogen metabolism of Rambouillet ewe lambs. Forty Rambouillet ewe lambs with an initial weight of $41.06 \pm$ $3.9 \mathrm{~kg}$ were randomly assigned to one of four experimental diets, namely $0,20,40$ and $60 \mathrm{~g}$ of natural zeolite (Comercializadora Omega ${ }^{\circledR}$ México) per kg dietary dry matter in a completely randomized design and sixteen ewe lambs were used in a 4 x 4 Latin square metabolism study. Performance was not modified by natural zeolite levels in the diet, and daily gain showed a quadratic response. Ammonia concentration at 8 and 12 hours increased linearly with zeolite. Zeolite increased ruminal pH linearly at 8 and 12 hours. Acetate and butyrate presented a quadratic response, and total ruminal volatile fatty acid concentration was linearly increased by zeolite. Nitrogen retention showed a linear and quadratic response to zeolite. The estimated fractions of protein digested in the small intestine, when rumen-fermentable energy was limiting (PDIE) and when rumen-fermentable nitrogen was limiting, showed a linear and quadratic response to zeolite. PDIE was positively correlated $(r=0.96)$ with average daily gain.
\end{abstract}

Keywords: Sheep, ammonium, ruminal fermentation, productive, soluble nitrogen

\# Corresponding author: hector.lee@uaslp.mx

\section{Introduction}

Natural zeolites are aluminium silicates, which can capture ammonium ions $\left(\mathrm{NH}_{4}{ }^{+}\right)$, reducing the rate of their release and absorption from the rumen. It has therefore been suggested that their inclusion in ruminant diets favourably affects the nutritional efficiency of ruminants by improving the efficiency of nitrogen (N) utilization by rumen microbes (Ruiz et al., 2007). This may be useful when dietary urea is rapidly hydrolysed to ammonia $\left(\mathrm{NH}_{3}\right)$ in the rumen, a characteristic that may be partially responsible for the low efficiency of $\mathrm{N}$ capture in the rumen by ruminal bacteria (Sadeghi \& Shawrang, 2006; Calsamiglia et al., 2010). Therefore, $\mathrm{NH}_{3}$ fed in excess can be detrimental to the production efficiency of ruminants (Bartley et al., 1981) and can contribute to environmental pollution (Broderick et al., 2009; Moshoeshoe et al., 2017).

Even though it was reported that zeolites are capable of sequestering and, subsequently, releasing proportionately 0.15 of the $\mathrm{NH}_{4}{ }^{+}$present in rumen contents (White \& Ohlrogge, 1974), Sweeney et al. (1980) did not find an effect of synthetic zeolite on rumen ammonia $\left(\mathrm{NH}_{3}{ }^{+}\right)$concentration. Regarding the performance effects on beef and dairy cattle that consume zeolites, feed intake has been reported to be increased (McCollum \& Galyean, 1983; Eroglu et al., 2017), but results have been inconsistent, possibly due to variations in the ratio of zeolite to urea or zeolite to rumen degradable protein in the diet. Sadeghi \& Shawrang (2006) included $30 \mathrm{~g} / \mathrm{kg}$ of zeolite in a diet that contained $20 \mathrm{~g} / \mathrm{kg}$ of urea and observed a decreased ruminal ammonia $\mathrm{N}$ concentration, increased fibre digestibility, and improved performance in Holstein steers. Based on these considerations, the objective of this study was to evaluate the effects of 
adding three levels of natural zeolite to growing rations for ewe lambs, while maintaining the same level of urea, on productive performance, ruminal fermentation, $\mathrm{N}$ metabolism and live weight changes.

\section{Materials and Methods}

This work was conducted in accordance with ethical standards and approved by the ethics and biosafety committee of the Universidad Autonoma de San Luis Potosí. The experiment was carried out in Soledad de Graciano Sanchez, San Luis Potosi, México, at a latitude $22^{\circ} 14^{\prime} 5.8^{\prime \prime}$, longitude $22^{\circ} 14^{\prime} 5.8^{\prime \prime}$, and altitude $1835 \mathrm{~m}$.

Forty Rambouillet ewe lambs with initial weights of $41.06 \pm 3.9 \mathrm{~kg}$ were randomly assigned to one of four experimental diets, which contained $0 \mathrm{~g}, 20 \mathrm{~g}, 40 \mathrm{~g}$ and $60 \mathrm{~g}$ of natural zeolite (Comercializadora Omega ${ }^{\circledR}$ México) per kg dietary dry matter (DM) (Table 1) and $15 \mathrm{~g} / \mathrm{kg}$ of urea. The diet was offered as a total mixed ration, and ewe lambs were housed in individual pens equipped with feed and water bowls. Feed was provided at 08:00 and 15:00. Ewe lambs were adapted to their experimental diets for eight days and the study lasted 52 days. All ewe lambs had free access to feed to ensure $100 \mathrm{~g}$ of orts per $\mathrm{kg}$ of the amount fed daily and feed intake was recorded daily. The lambs were weighed at the beginning and the end of each period to estimate average daily gain (ADG) and feed conversion (FC) was expressed as the ratio of feed intake to ADG.

Table 1 Formulation and chemical composition (\% DM basis) of the basal diet fed to ewe lambs during 52 days of feeding

\begin{tabular}{|c|c|c|c|c|}
\hline & \multicolumn{4}{|c|}{ Natural zeolite (g/kg) } \\
\hline & 0 & 20 & 40 & 60 \\
\hline \multicolumn{5}{|l|}{ Ingredients (\% DM) } \\
\hline Forage sorghum & 40 & 40 & 40 & 40 \\
\hline Urea & 1.5 & 1.5 & 1.5 & 1.5 \\
\hline Soybean meal & 2.1 & 1.9 & 2.1 & 2.12 \\
\hline Ground sorghum & 21.5 & 18.45 & 12.22 & 14.6 \\
\hline Corn grain & 24.1 & 25.35 & 29.34 & 24.9 \\
\hline Cane molasses & 9.3 & 9.3 & 9.34 & 9.38 \\
\hline Minerals and vitamin premix* & 1.5 & 1.5 & 1.5 & 1.5 \\
\hline Natural zeolite & 0 & 2 & 4 & 6 \\
\hline \multicolumn{5}{|l|}{ Chemical composition (\% of DMs) } \\
\hline Dry matter (\%) & 90 & 90 & 90 & 90 \\
\hline Crude protein (\%) & 13.1 & 13.1 & 13.0 & 13.1 \\
\hline Neutral detergent fibre (\%) & 40.4 & 42.8 & 39.1 & 38.7 \\
\hline Ether extract (\%) & 4.2 & 3.98 & 3.27 & 2.87 \\
\hline Ash (\%) & 7.5 & 8 & 9.5 & 11.65 \\
\hline
\end{tabular}

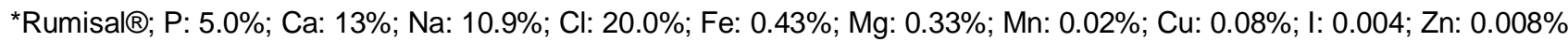

The same four diets that were used in the growth trial were randomly assigned to 16 Rambouillet ewe lambs (1 year; $42.7 \pm 2.9 \mathrm{~kg}$ ), which were housed in individual metabolism pens in a naturally ventilated barn. Water and diets were offered at 8:00 and 17:00, and the lambs had free choice access to feed. There were four 15-day experimental periods, each with 10 days for adaptation and 5 days for sampling. Feed, faeces, urine and orts were collected during the collection period. Ruminal fluid was obtained in the last three days of each period $(60 \mathrm{~mL})$ via oesophageal tube before feeding, and 4,8 and 12 hours post feeding. $\mathrm{pH}$ was measured immediately with a pH meter (Benchtop Cole Parmer 05669-20, Vernon Hills, IL, USA). Samples were acidified with $1 \mathrm{~mL}$ of sulphuric acid $(30 \%)$ and then frozen at $-20^{\circ} \mathrm{C}$ until laboratory analysis. Ten millilitres rumen fluid was mixed with metaphosphoric acid (5 to 1 ratio) and centrifuged $(40,000 \times g \times 10$ 
min. The supernatant was used to measure the proportion of volatile fatty acids (VFA) by gas chromatography (Erwin et al., 1961). Ammonia N was measured using the indophenol method (McCullough, 1967). Feed samples were analysed according to AOAC (1990) for dry matter (DM) (method number 981.10), crude protein (CP) (method number 967.03), and neutral detergent fibre (NDF) and acid detergent fibre (ADF), according to Van Soest et al. (1991) with a heat-stable amylase included in the NDF, and expressed including residual ash. The Henderson-Hasselbalch equation and ruminal $\mathrm{pH}$ were used to estimate the amount of $\mathrm{NH}_{3}$ and $\mathrm{NH}_{4}{ }^{+}$in the rumen to evaluate whether zeolites affected $\mathrm{NH}_{4}{ }^{+}$capture (Abdoun et al., 2007; Valpotić et al., 2017).

Protein digestibility was estimated with the system of digestible protein in the intestine (PDI), according to INRA (1989), which estimates the value of truly digestible protein in the intestine: i) PDIN, defined as the amount of digestible protein in the small intestine when energy and other nutrients are not limiting microbial protein synthesis; and ii) PDIE, defined as the amount of digestible protein in the small intestine when rumen degradable nitrogen and other nutrients are limiting for ruminal microorganisms, with the equation described by Ramos et al. (1995):

PDIA = (CP) (1.11) (1- Deg) (dsi); PDIMN= (CP) (0.64) (Deg - 0.1); PDIME = 0.093 (MOF - EE); PDIN = PDIA + PDIMN; PDIE = PDIA + PDIME.

where: $\mathrm{CP}=$ crude protein $\mathrm{g} / \mathrm{kg}$ dry matter $(\mathrm{DM})$

Deg = degradable protein in rumen $(\mathrm{kg} / \mathrm{kg} \mathrm{CP})$

$\mathrm{dsi}=$ true digestibility in the small intestine of the dietary protein not degraded in rumen

PDIA = dietary protein not degraded in rumen truly digestible in small intestine ( $\mathrm{g} / \mathrm{kg} \mathrm{DM}$ )

PDIMN = amount of microbial protein that could be synthesized in the rumen of the nitrogen dietary degraded in rumen, when energy and other nutrients are not limiting ( $\mathrm{g} / \mathrm{kg} \mathrm{DM})$

PDIME = amount of microbial protein that could be synthesized of the energy available in the rumen, when the degradable nitrogen in rumen and other nutrients are not limiting factors ( $\mathrm{g} / \mathrm{kg} \mathrm{DM}$ )

MOF = content of fermentable organic matter in rumen ( $\mathrm{g} / \mathrm{kg} \mathrm{DM})$

$\mathrm{EE}=$ ether extract $(\mathrm{g} / \mathrm{kg} \mathrm{DM})$

Feed samples of each treatment were dried, weighed, and put in Ankom bags (0.35 g per bag) and prepared for the in vitro digestibility technique by Tilley \& Terry (1963), as modified by Alexander \& McGowan (1966). Samples were incubated for 48 hours with a mixture of $90 \mathrm{~mL}$ McDougall (1948) buffer solution and $10 \mathrm{~mL}$ rumen liquid obtained from the ewe lambs in each stage of the experiment.

The results were analysed according to a completely randomized design using each ewe lamb as an experimental unit (Steel et al., 1997). Orthogonal polynomial contrasts were used to verify linear or quadratic effects for natural zeolite level on ewe lamb performance. The metabolism results were analysed according to a replicated, $4 \times 4$ Latin square design (Steel et al., 1997). Variables measured more than once were analysed using the repeated measures procedure. The correlations between PDIE, PDIN and productive performance (average daily gain, feed intake and feed conversion) were estimated. Data were analysed with JMP7 software (Sall et al., 2012). A P-value of 0.05 was selected as the significance level.

\section{Results}

Dry matter intake and feed conversion were not modified by the level of natural zeolite in the diet (Table 2), while daily gain showed a quadratic response $(P<0.05)$ (Table 2). The addition of zeolite increased the $\mathrm{NH}_{3}$ concentration at 8 and 12 hours (linear $\left.P<0.05\right)$ (Table 3). Zeolite also increased ruminal $\mathrm{pH}$ (linear effect $(P<0.05)$ (Table 3$)$ at 8 and 12 hours. Acetate and butyrate presented a quadratic response $(P<0.01)$, and total VFA concentration was linearly increased $(P<0.01)$ in ruminal liquid as a result of the addition of zeolite (Table 3). Nitrogen retention showed a linear and quadratic response $(P<0.05$, Table 4$)$ to increasing level of natural zeolite, and the PDIE and PDIN estimated fractions showed a linear and quadratic response $(P<0.05)$. The PDIE was positively correlated $(r=0.96)(P \geq 0.03)$ with average daily gain, while PDIN with $\mathrm{NH}_{3}(r=0.95 ; P=0.04)$ and intake were positively related to retained $\mathrm{N}(r=0.97$; $P=0.02)$.

\section{Discussion}

The use of natural zeolite had no effect on DM intake (Table 2) as observed in previous studies using natural and synthetic zeolite (Sherwood et al., 2006; Cole et al., 2007; Dschaak et al., 2010). Johnson et al. (1988) reported that lactating dairy cows decreased feed intake when synthetic zeolite was added at $20 \mathrm{~g} / \mathrm{kg}$, which is a low dose if it is expressed as a proportion of DM or metabolic weight. 
Table 2 Performance of ewe lambs fed various levels of natural zeolite

\begin{tabular}{lccccccc}
\hline & \multicolumn{4}{c}{ Natural zeolite (g/kg) } & \multicolumn{2}{c}{$\boldsymbol{P}$-value } \\
\cline { 2 - 8 } & $\mathbf{0}$ & $\mathbf{2 0}$ & $\mathbf{4 0}$ & $\mathbf{6 0}$ & SEM & Linear & Quadratic \\
\hline Initial weight (kg) & 43.2 & 42.9 & 43.6 & 43.5 & 0.82 & - & - \\
Final weight (kg) & 48.8 & 49.6 & 51.5 & 50.1 & 0.81 & - & - \\
Intake DM Intake (g/d) & $1,628^{\mathrm{b}}$ & $1,558^{\mathrm{c}}$ & $1,644^{\mathrm{b}}$ & $1,895^{\mathrm{a}}$ & 14.21 & 0.21 & 0.89 \\
Daily live weight gain (g/d) & 140 & 167 & 197 & 165 & 19.14 & 0.72 & 0.05 \\
Feed conversion F : G & $11.63^{\mathrm{a}}$ & $9.30^{\mathrm{ab}}$ & $8.31^{\mathrm{ab}}$ & $11.3^{\mathrm{a}}$ & 0.71 & 0.87 & 0.22 \\
\hline
\end{tabular}

DM: dry matter; SEM: standard error of mean

${ }^{a b c}$ Means within row with different superscripts differ $(P<0.05)$

Table 3 Ruminal ammonia nitrogen concentration, $\mathrm{pH}$ and volatile fatty acid concentration of ewe lambs fed various levels of natural zeolite

\begin{tabular}{|c|c|c|c|c|c|c|c|}
\hline & \multicolumn{4}{|c|}{ Natural Zeolite (g/kg) } & \multirow{2}{*}{$\begin{array}{l}\text { SEM } \\
\text { SEM }\end{array}$} & \multicolumn{2}{|c|}{$P$-value } \\
\hline & 0 & 20 & 40 & 60 & & Linear & Quadratic \\
\hline \multicolumn{8}{|l|}{$\mathrm{NH}_{3}(\mathrm{mg} / \mathrm{dL})$} \\
\hline Before feeding & 0.04 & $0.06^{\mathrm{a}}$ & $0.02^{\mathrm{a}}$ & $0.05^{\mathrm{a}}$ & 0.019 & 0.94 & 0.32 \\
\hline $4 \mathrm{~h}$ post feeding & $0.03^{\mathrm{ab}}$ & $0.04^{\mathrm{a}}$ & $0.02^{\mathrm{b}}$ & $0.03^{\mathrm{ab}}$ & 0.007 & 0.80 & 0.73 \\
\hline $8 \mathrm{~h}$ post feeding & $0.01^{\mathrm{c}}$ & $0.02^{\mathrm{bc}}$ & $0.04^{\mathrm{a}}$ & $0.03^{\mathrm{ab}}$ & 0.005 & 0.01 & 0.06 \\
\hline $12 \mathrm{~h}$ post feeding & $0.02^{\mathrm{b}}$ & $0.04^{\mathrm{ab}}$ & $0.05^{\mathrm{a}}$ & $0.04^{\mathrm{a}}$ & 0.006 & 0.01 & 0.03 \\
\hline \multicolumn{8}{|l|}{$\mathrm{NH}_{4}{ }^{+}$} \\
\hline Before feeding & 6.8 & 7.2 & 7.1 & 8.1 & 0.83 & 0.32 & 0.72 \\
\hline $4 \mathrm{~h}$ post feeding & $5.24^{b}$ & $9.08^{\mathrm{a}}$ & $5.55^{\mathrm{b}}$ & $6.35^{\mathrm{ab}}$ & 0.74 & 0.95 & 0.05 \\
\hline $8 \mathrm{~h}$ post feeding & $3.66^{\mathrm{b}}$ & $5.08^{\mathrm{ab}}$ & $5.86^{a}$ & $6.82^{\mathrm{a}}$ & 0.51 & 0.01 & 0.67 \\
\hline $12 \mathrm{~h}$ post feeding & 5.80 & 6.77 & 5.48 & 6.44 & 0.37 & 0.66 & 0.88 \\
\hline \multicolumn{8}{|l|}{ pH } \\
\hline Before feeding & $6.9^{\mathrm{a}}$ & $7.1^{\mathrm{a}}$ & $6.7^{\mathrm{b}}$ & $7.0^{\mathrm{a}}$ & 0.05 & 0.37 & 0.04 \\
\hline $4 \mathrm{~h}$ post feeding & $6.5^{\mathrm{a}}$ & $6.9^{\mathrm{a}}$ & $6.7^{\mathrm{a}}$ & $6.9^{\mathrm{a}}$ & 0.19 & 0.21 & 0.54 \\
\hline $8 \mathrm{~h}$ post feeding & $6.5^{\mathrm{c}}$ & $6.7^{\mathrm{ab}}$ & $7.0^{\mathrm{a}}$ & $6.8^{\mathrm{a}}$ & 0.06 & 0.01 & 0.05 \\
\hline $12 \mathrm{~h}$ post feeding & $6.7^{\mathrm{b}}$ & $6.9^{\mathrm{a}}$ & $7.1^{\mathrm{a}}$ & $7.0^{\mathrm{a}}$ & 0.05 & 0.06 & 0.01 \\
\hline \multicolumn{8}{|c|}{ VFA (mol/100 mol of total VFA) } \\
\hline Acetate & $64.2^{\mathrm{a}}$ & $67.9^{\mathrm{a}}$ & $66.0^{\mathrm{a}}$ & $63.0^{\mathrm{a}}$ & 1.50 & 0.22 & 0.01 \\
\hline Butyrate & $13.5^{\mathrm{a}}$ & $13.9^{\mathrm{a}}$ & $14.4^{\mathrm{a}}$ & $13.9^{\mathrm{a}}$ & 0.30 & 0.42 & 0.01 \\
\hline Propionate & $22.1^{\mathrm{a}}$ & $18.1^{\mathrm{a}}$ & $19.5^{\mathrm{a}}$ & $22.9^{\mathrm{a}}$ & 1.91 & 0.38 & 0.37 \\
\hline Total (mmol/L) & $37.5^{\mathrm{b}}$ & $38.5^{\mathrm{b}}$ & $48.5^{\mathrm{a}}$ & $50.3^{\mathrm{a}}$ & 2.27 & 0.01 & 0.70 \\
\hline
\end{tabular}

VFA: volatile fatty acids; SEM: standard error of mean; $\mathrm{NH}_{3}$ : ammonia; $\mathrm{NH}_{4}{ }^{+}$: ammonium

${ }^{a b c}$ Means within row with different superscripts differ $(P<0.05)$ 
Table 4 In vitro dry matter and protein digestibility, nitrogen balance, and digestible protein in the intestine of diets with various levels of natural zeolite

\begin{tabular}{lccccccc}
\hline & \multicolumn{4}{c}{ Natural Zeolite (g/kg) } & \multicolumn{3}{c}{$P$-value } \\
\cline { 2 - 8 } & $\mathbf{0}$ & $\mathbf{2 0}$ & $\mathbf{4 0}$ & $\mathbf{6 0}$ & $\mathbf{S E M}$ & Linear & Quadratic \\
\hline In vitro DM digestibility, \% & 77.94 & 66.36 & 73.50 & 73.83 & 12.64 & 0.06 & 0.34 \\
In vitro protein digestibility, \% & 79.59 & 84.46 & 73.20 & 78.79 & 16.64 & 0.32 & 0.12 \\
DM intake, g/d & $1628.2^{\mathrm{b}}$ & $1558.2^{\mathrm{c}}$ & $1644.2^{\mathrm{b}}$ & $1895.7^{\mathrm{a}}$ & 14.41 & 0.01 & 0.01 \\
Nitrogen (N) intake, g/d & $34.03^{\mathrm{b}}$ & $29.99^{\mathrm{c}}$ & $34.19^{\mathrm{b}}$ & $36.5^{\mathrm{a}}$ & 0.29 & 0.01 & 0.01 \\
N faeces, g/d & $10.91^{\mathrm{a}}$ & $11.63^{\mathrm{a}}$ & $10.32^{\mathrm{a}}$ & $5.2^{\mathrm{b}}$ & 0.92 & 0.01 & 0.01 \\
N urine, g/d & 1.52 & 1.52 & 1.94 & 1.8 & 0.21 & 0.14 & 0.70 \\
N retained, g/d & $21.58^{\mathrm{b}}$ & $16.83^{\mathrm{c}}$ & $21.93^{\mathrm{b}}$ & $29.4^{\mathrm{a}}$ & 0.87 & 0.01 & 0.01 \\
PDI & & & & & & & \\
PDIA, g/kg & $13.65^{\mathrm{a}}$ & $32.29^{\mathrm{a}}$ & $28.60^{\mathrm{c}}$ & $34.45^{\mathrm{b}}$ & 10.70 & 0.01 & 0.05 \\
PDIMN, g/kg & $45.30^{\mathrm{b}}$ & $44.31^{\mathrm{a}}$ & $41.29^{\mathrm{a}}$ & $41.81^{\mathrm{a}}$ & 10.56 & 0.25 & 0.75 \\
PDIME, g/kg & $37.11^{\mathrm{a}}$ & $36.22^{\mathrm{a}}$ & $34.03^{\mathrm{a}}$ & $33.03^{\mathrm{a}}$ & 4.75 & 0.10 & 0.97 \\
PDIN, g/kg & $58.95^{\mathrm{c}}$ & $76.61^{\mathrm{a}}$ & $69.89^{\mathrm{b}}$ & $76.26^{\mathrm{a}}$ & 0.13 & 0.01 & 0.01 \\
PDIE, g/kg & $50.76^{\mathrm{c}}$ & $68.51^{\mathrm{a}}$ & $62.64^{\mathrm{b}}$ & $67.49^{\mathrm{a}}$ & 1.30 & 0.01 & 0.01 \\
\hline
\end{tabular}

SEM: standard error of the mean; DM: dry matter; PDI: digestible protein in the intestine

PDIA: dietary protein not degraded in rumen truly digestible in the small intestine, PDIMN: amount of microbial protein that could be synthesized in the rumen of the nitrogen dietary degraded in rumen, when energy and other nutrients are not limiting, PDIME: amount of microbial protein that could be synthesized of the energy available in the rumen, when the degradable nitrogen in rumen and other nutrients are not limiting factors PDIE, PDIN: protein digestible in the small intestine when rumen fermentable energy or nitrogen, respectively, are limiting.

Natural zeolites with urea showed a quadratic response in ADG, with the maximum gain with $40 \mathrm{~g} / \mathrm{kg}$. Pond (1984) reported that only when clinoptilolite was added at $20 \mathrm{~g} / \mathrm{kg}$ dietary DM did it promote growth of lambs. In that experiment a positive response was observed with $40 \mathrm{~g} / \mathrm{kg} \mathrm{DM}$. However, even when this was associated with a decrease in ruminal $\mathrm{NH}_{3}$ concentration (Sadeghi \& Shawrang, 2006), results from this experiment did not show any beneficial effect on $\mathrm{NH}_{3}$ or $\mathrm{NH}_{4}^{+}$concentrations. The unique benefit of zeolites in rumen fermentation can be associated with a higher $\mathrm{pH}$, which stimulates fibrolytic bacteria, which is reflected in the acetate concentration (Pan et al., 2003). The higher $\mathrm{pH}$ could be related to the high $\mathrm{NH}_{3}$ concentration. When urea is administered, the $\mathrm{pH}$ can increase rapidly in the rumen (Abdoun et al., 2007). This contrasts with other hypotheses regarding the mechanisms of action of zeolites.

Deligiannis et al. (2005) used a natural zeolite in growing lambs that were infected with gastrointestinal nematodes and found that natural zeolite reduced the establishment of the nematodes and resulted in differences in ADG and DM intake. Since the ewe lambs were dewormed in this study, this may be an explanation for the increased digestibility. However, Grabherr et al. (2009) added zeolite at 0,10 and $20 \mathrm{~g} / \mathrm{kg}$ DM in cows and observed that supplementation led to a significantly reduced ruminal DM and organic matter digestibility, which was also reported by other authors (Johnson et al., 1988; Cole et al., 2005; Dschaak et al., 2010; Stojkovic et al., 2012).

Rumen $\mathrm{NH}_{3}$ and $\mathrm{NH}_{4}^{+}$concentrations in the first hours were not affected by the addition of natural zeolite, but after 8 and 12 hours the concentrations of both increased. This contrasts with the results from Kardaya et al. (2012), who reported that lambs fed diets without urea, zeolite or urea-impregnated zeolite rations produced similar ruminal $\mathrm{NH}_{3}$ concentrations, and those from Montalvo et al. (2005), who reported that zeolite could reduce the concentration of free $\mathrm{NH}_{3}$ in the supernatant of the anaerobic digestion process of synthetic and piggery wastes, which may be different in the anaerobic conditions in the rumen.

Sadeghi \& Shawrang (2006) reported low levels of ruminal $\mathrm{NH}_{3}$ concentration in steers that received $20 \mathrm{~g} / \mathrm{kg}$ of urea and $0 \mathrm{~g} / \mathrm{kg}$ of natural zeolite at $0,2.5$, and 5.5 hours post feeding, unlike the steers that received $30 \mathrm{~g} / \mathrm{kg}$ of natural zeolite and $20 \mathrm{~g} / \mathrm{kg}$ of urea, and the concentration of ruminal $\mathrm{NH}_{3}$ concentration was higher. Stephenson \& Huff (1992) reported that natural zeolites could function as $\mathrm{NH}_{3}$ reserves in the rumen and could increase dietary $\mathrm{N}$ utilization. Through infrared spectroscopy, Michael et al. (1991) showed 
that naturally occurring zeolite can absorb urea under aerobic conditions from aqueous or ethanolic solutions. However, that does not mean it can function in the same way in the rumen.

All ruminal $\mathrm{pH}$ values in the present study were in the normal range of 6.5 to 7 , where most of the ammonia would be present in the form of $\mathrm{NH}_{4}{ }^{+}$, as reported by Abdoun et al. (2007). Higher ruminal pH values as a result of zeolite treatment could be due to high ruminal $\mathrm{NH}_{3}$ as a result of rapid urea hydrolysis in the rumen. The rise in ruminal $\mathrm{pH}$ as a result of the increase in ruminal $\mathrm{NH}_{3}-\mathrm{N}$ was also demonstrated by Pan et al. (2003). However, this was in contrast with Kardaya et al. (2012), who found that the addition of zeolite decreased ruminal $\mathrm{pH}$, which indicated that zeolite was able to capture $\mathrm{NH}_{3}$ through its cation exchange capacity.

The total VFA concentration tended to increase $(P=0.01)$ when the ewe lambs were fed zeolite, whereas molar proportions of acetate and butyrate responded quadratically to increasing levels of zeolite. Higher acetate concentrations in lambs fed urea rations were associated with its higher $\mathrm{NH}_{3}$ concentration and its higher $\mathrm{pH}$ value. This finding is fairly in agreement with Pan et al. (2003), who revealed that increases in ruminal $\mathrm{NH}_{3}-\mathrm{N}$ might increase ruminal $\mathrm{pH}$ and total VFAs and stimulate cellulolytic bacteria activity in the rumen. Dschaak et al. (2010) observed that the inclusion of zeolite in the diet of lactating dairy cows decreased total VFA concentration. However, Bosi et al. (2002) observed that the inclusion of zeolite in the diet of lactating dairy cows had no effect on the concentration and molar proportion of VFA.

The concentration of $\mathrm{NH}_{3}-\mathrm{N}$ in the rumen is an indicator of the rate of ruminal $\mathrm{N}$ degradation, the concentration of rumen-degraded $\mathrm{N}$ above microbial needs, and the amount of dietary energy available for the ruminal microorganisms (Li et al., 2011). Increased consumption of NDF can decrease ruminal $\mathrm{NH}_{3}$ concentrations (Royes et al., 2001) for greater microbial protein synthesis and concurrent higher demand for rumen degradable protein. Lizarazo et al. (2014) reported that when sheep were fed a diet in which the use of coated urea did not affect the urinary and faecal $\mathrm{N}$ excretion or the retained $\mathrm{N}$, there were changes in the efficiency utilization of the $\mathrm{N}$ body among treatments. In contrast, the authors found that treatments of urea + zeolite decreased faecal $\mathrm{N}$ and increased $\mathrm{N}$ retention. Furthermore, $\mathrm{N}$ can be recycled by ruminants to compensate for differences in the release time of $N$ in the rumen (Reynolds \& Kristensen, 2008; Toprak et al., 2016). It is now well established that $\mathrm{N}$ retention depends on the intake of $\mathrm{N}$ and the amount of fermentable carbohydrate in the diet (Sarwar et al., 2003). However, Sherwood et al. (2006) found that $\mathrm{N}$ mass balance was not affected by the addition of zeolite clay in steers fed with $12 \mathrm{~g}$ zeolite per $\mathrm{kg}$. Research with other species has shown zeolite clay to be effective in adsorbing $\mathrm{N}$, therefore having the ability to reduce $\mathrm{N}$ volatilization losses. The lack of a response to zeolite in the current study could be due to variations in the clays and the methodology for assessing $\mathrm{N}$ losses. Additionally, zeolite clay may not have the cation exchange potential needed for the conditions in open pens as opposed to confinement (Sherwood et al., 2006).

The PDIE value was also higher for zeolite treatments. Tabulated PDI values of the diets calculated from in vitro data have to be increased by the addition of zeolite. Thus, the nutrients available for the protein synthesis of rumen micro-organisms probably led to similar levels of amino acids to the intestines (GigerReverdina et al., 2015), whereas in this study, PDIN was greater than the PDIE, indicating that dietary rumen degradable $\mathrm{N}$ was suitable, which could explain the high correlation $(r=0.96 ; P=0.03)$ between PDIE and daily live weight gain.

\section{Conclusion}

The inclusion of 20 to $40 \mathrm{~g} / \mathrm{kg}$ zeolite in the diet had a positive effect on the average daily gain, ruminal fermentation patterns and PDIE estimated, and nitrogen retention increased with the inclusion of $60 \mathrm{~g} / \mathrm{kg}$, but more research is necessary to determine the mechanisms of action in the rumen.

\section{Acknowledgements}

Authors thank financial support to FAI-UASLP C18-FAI-05-34.34. The authors acknowledge Comercializadora Omega ${ }^{\circledR}$ (San Luis Potosi, Mexico) for providing the natural zeolite.

\section{Authors' Contributions}

The authors' responsibilities were as follows HALR: conceptualized the study; JARJ and JACJ: conducted the animal experiment, collected the biological samples, and performed the analyses; JARJ and HALR: performed the analyses; JMPR, GDM, and RRR: contributed reagents and helped to interpret the data; AV, JARJ, and HALR: prepared the manuscript; JARJ, JMPR, GDM and HALR: contributed to the interpretation of the data; and all authors: read and approved the final manuscript. 


\section{Conflict of Interest Declaration}

The authors declare that there is no conflict of interests regarding the publication of this article.

\section{References}

Abdoun, K., Stumpff, F. \& Martens, H., 2007. Ammonia and urea transport across the rumen epithelium: A review. Anim. Health Res. Rev. 7, 43-59.

Alexander, R.H. \& McGowan, M., 1966. The routine determination of in vitro digestibility of organic matter in forges an investigation of the problems associated with continuous large-scale operation. J. Br. Grassl. Soc. 21, $140-149$.

AOAC, 1990. Official methods of analysis. 16th edition. Association of Official Analytical Chemists. William Byrd Press, Richmond, VA, USA.

Bartley, E.E., Avery, T.B., Nagaraja, T.G., Watt, B.R., Davidovich, A., Galitzer, S. \& Lassman, B., 1981. Ammonia toxicity in cattle. V. Ammonia concentration of lymph and portal, carotid and jugular blood after the ingestion of urea. J. Anim. Sci. 53, 494-498.

Bosi, P., Creston, D. \& Casini, L., 2002. Production performance of dairy cows after the dietary addition of clinoptilolite. Ital. J. Anim. Sci. 1,187-195.

Broderick, G.A., Stevenson, M.J. \& Patton, R.A., 2009. Effect of dietary protein concentration and degradability on response to rumen-protected methionine in lactating dairy cows. J. Dairy Sci. 92, 2719-2728.

Calsamiglia, S., Ferret, A., Reynolds, C.K., Kristensen, N.B. \& Van Vuuren, A.M., 2010. Strategies for optimizing nitrogen use by ruminants. Animal 4, 1184-1196.

Cole, N.A., Clark, R.N., Todd, R.W., Richardson, C.R., Gueye, A., Greene, L.W. \& McBride, K., 2005. Influence of dietary crude protein concentration and source on potential ammonia emissions from beef cattle manure. J. Anim. Sci. 83, 722-731.

Deligiannis, K., Lainas, T., Arsenos, G., Papadopoulos, E., Fortomaris, P., Kufidis, D., Stamataris, C. \& Zygoyiannis, D., 2005. The effect of feeding clinoptilolite on food intake and performance of growing lambs infected or not with gastrointestinal nematodes. Livest. Prod. Sci. 96, 195-203.

Dschaak, C.M., Eun, J.S., Young, A.J., Stott, R.D. \& Peterson, S., 2010. Effects of supplementation of natural zeolite on intake, digestion, ruminal fermentation, and lactational performance of dairy cows. Prof. Anim. Sci. 26, 647-654.

Eroglu, N., Emekci, M. \& Athanassiou, C., 2017. Applications of natural zeolites on agriculture and food production. J. Sci. Food Agric. 97, 3487-3499.

Erwin, E.S., Marco, G.J. \& Emery, E., 1961. Volatile fatty acid analysis of blood and rumen fluid by gas chromatography. J. Dairy Sci. 44, 1768-1776.

Giger-Reverdina, S., Maaroufia, C., Peyronnet, C. \& Sauvant, D., 2015. Effects of particle size and dietary nitrogen content on the nutritive value of pea-based diets in mid-lactation goats. Anim. Feed Sci. Technol. 210, 56-65.

Grabherr, H., Spolders, M., Fürll, M. \& Flachowsky, G., 2009. Effect of several doses of zeolite A on feed intake, energy metabolism and on mineral metabolism in dairy cows around calving. J. Anim. Physiol. Anim. Nutr. 93, 221-236.

INRA (Institut National de la Recherche Agronomique), 2010. Tableaux de la valeur des aliments Alimentation des bovins, ovins et caprins. Besoins des animaux - Valeurs des aliments. Tables INRA 2007, mise à jour 2010 (Nutrition of cattle, sheep and goats: animal needs - values of feeds. INRA Tables 2007. Revision 2010). Quae, Versailles Cedex, France, pp. 188-290.

Johnson, M.A., Sweeney, T.F. \& Muller, L.D., 1988. Effects of feeding synthetic zeolite A and sodium bicarbonate on milk production nutrient digestion, and rate of digesta passage in dairy cows. J. Dairy Sci. 71, 946-953.

Kardaya, D., Sudrajat, D. \& Dihansih, E., 2012. Efficacy of dietary urea-impregnated zeolite in improving rumen fermentation characteristics of local lamb. Media Paternak 35 (3), 207-213.

Li, Q., Gao, Y., Cao, Y., Feng, Z. \& Li, J., 2011. Effects of rumen-degradable protein balance on rumen fermentation in continuous culture fermenters. Front. Agri. China 5 (4), 598-604.

Lizarazo, A.C., Mendoza, G.D., Kú, J., Melgoza, L.M. \& Crosby, M., 2014. Effects of slow-release urea and molasses on ruminal metabolism of lambs fed with low-quality tropical forage. Small Rumin. Res. 116, 28-31.

McDougall, E., 1948. Studies on ruminant saliva. The composition and output of sheep's saliva. Biochem J. 43, 99-109.

McCollum, F.T. \& Galyean, M.L., 1983. Effects of clinoptilolite on rumen fermentation, digestion and feedlot performance in beef steers fed high concentrate diets. J. Anim. Sci. 56, 517-524.

McCullough, H., 1967. The determination of ammonia in whole blood by direct colorimetric method. Clini. Chem. Acta 17, 297-298.

Michael, B.D., Gerasimowicz, W.V., Stockette, M. \& Eberl, D.D., 1991. Infrared spectroscopic examination of the interaction of urea with the naturally occurring zeolite clinoptilolite. Microchem. J. 44, 130-139.

Montalvo, S., Daz, F., Guerrero, L., Sanchez, E. \& Borj, R., 2005. Effect of particle size and doses of zeolite addition on anaerobic digestion processes of synthetic and piggery wastes. Process Biochem. 40, 1475-1481.

Moshoeshoe, M., Silas, M. \& Obuseng, V., 2017. A review of the chemistry, structure, properties and applications of zeolites. J. Maler. Sci. 7 (5), 196-221.

Pan, J., Suzuki, T., Koike, S., Ueda, K. \& Kobayashi, Y., 2003. Effect of urea infusion into the rumen on liquid-and particle associated fibrolytic enzyme activities in steers fed low quality grass hay. Anim. Feed Sci. Technol. 104, 13-27.

Pond, W.G., 1984. Response of growing lambs to clinoptilolite or zeolite NaA added to corn, corn-fish meal and cornsoybean meal diets. J. Anim. Sci. 59, 1320-1328. 
Ramos, J.A., Mendoza, M.G., Arand, I.E. García, B.C. \& Bárcena, G.R., 1995. Caracterización del nitrógeno del pasto estrella con dos sistemas: proteína metabolizable y proteína cruda digestible. Rev. Fac. Agron. Luz. 12 (2), 209-220 (Eng. Abstr.).

Reynolds, S.M. \& Kristensen, N.B., 2008. Nitrogen recycling through the gut and the nitrogen economy of ruminants: An asynchronous symbiosis. J. Anim. Sci. 86, (E. Suppl.) E293-E305.

Royes, J.B., Brown, W.F., Martin, F.G. \& Bates, D.B., 2001. Source and level of energy supplementation for yearling cattle fed ammoniated hay. J. Anim. Sci. 79, 1313-1321.

Ruíz, O., Castillo, Y., Miranda, M.T., Elías, A., Arzola, C., Rodríguez, C. \& La, O., 2007. Levels of zeolite and their effects on the rumen fermentation of sheep fed alfalfa hay and concentrate. Cub. J. Agri. Sci. 41 (3), 241-245.

Sadeghi, A.A. \& Shawrang, P., 2006. The effect of natural zeolite on nutrient digestibility, carcass traits and performance of Holstein steers given a diet containing urea. Anim. Sci. 82, 163-167.

Sall, J., Lehman, A., Stephens, M. \& Creighton, L., 2012. JMP® Start statistics: A guide to statistics and data analysis. SAS Institute Inc, Cary, NC, USA.

Sarwar, M., Ajmal Khan, M. \& Mahr-un-Nisa., 2003. Nitrogen retention and chemical composition of urea treated wheat straw ensiled with organic acids or fermentable carbohydrate. Asian-Austral. J. Anim. Sci. 16, 1583-1592.

Sherwood, D.M., Erickson, G.E. \& Klopfenstein, T.J., 2006a. Nitrogen mass balance and cattle performance of steers fed clinoptilolite zeolite clay. p. 90 in Nebraska Beef Report, Univ. Nebraska, Lincoln.

Sherwood, D.M., Erickson, G.E. \& Klopfenstein, T.J., 2006b. Nitrogen mass balance and cattle performance of steers fed clinoptilolite zeolite clay. Nebraska Beef Cattle Reports. Paper 134. http://digitalcommons.unl.edu/animalscinbcr/134

Steel, G.D.R., Torrie, J.H. \& Dickey, D.A., 1997. Principles and procedures of statistics. A biometrical approach. McGraw-Hill Book Company, New York, USA.

Stephenson, R.G.A. \& Huff, J.L., 1992. Effect of molasses, sodium bentonite and zeolite on urea toxicity. Aust. J. Agric. Res. 43, 301-310.

Stojkovic, J., Ilic, Z., Milenkovic, M., Jasovic, B. \& Cilev, G., 2012. The effect of natural zeolite on fattening lambs' productions results. JHED. 1, 302-304.

Sweeney, T.F., Bull, L.S. \& Hemken, R.W., 1980. Effect of zeolite as a feed additive on growth performance in ruminants. J. Anim. Sci. 51 (Suppl.1), 401-409.

Tilley, J., \& Terry, R., 1963. A two-stage technique for the in vitro digestion of forage crops. J. Br.t Grassl. Soc. 18, 104-111.

Toprak, N., Yilmaz, A., Öztürk, E., Yigit, O. \& Cedden, F., 2016. Effect of micronized zeolite addition to lamb concentrate feeds on growth performance and some blood chemistry and metabolites. S. Afr. J. Anim. Sci. 46, 314-320.

Valpotić, H., Grăcner, D., Turke, R., Durićić, D., Vince, S., Folnožić, I., Lojkić, M., Žura-Žaja, I., Bedrica, L., Maćeśić, N., Getz, I., Dobraniž, T. \& Samardžija, M., 2017. Zeolite clinoptilolite nanoporus feed additive for animals of veterinary importance potentials and limitations. Period. Biol. 119, 159-172.

Van Soest, P.J., Robertson, J.B. \& Lewis, B.A., 1991. Methods for dietary fiber, neutral detergent fiber, and nonstarch polysaccharides in relation to animal nutrition. J. Dairy Sci. 74, 3583-3597.

White, J.L. \& Ohlrogge, A.J., 1974. Ion exchange materials to increase consumption of non-protein nitrogen in ruminants. Canadian patent number 939186. 